\title{
SUNDERMANN
}

Jurnal Ilmiah Teologi, Pendidikan, Sains, Humaniora dan Kebudayaan

pISSN: 1979-3588 | eISSN: 2715-8969

https://jurnal.sttsundermann.ac.id

\section{Ketika Keadilan Bertemu dengan Kasih}

\section{Sebuah Studi Perbandingan Antara Teori Keadilan Menurut John Rawls dan Reinhold Niebuhr}

\section{Oinike Natalia Harefa}

Silliman University Dumaguete, Philippines oinike21121986@gmail.com

\section{ARTICLE INFO}

Submitted: March 26, 2020

Review: March 29, 2020

Accepted: April 30, 2020

Published: May 06, 2020

\section{KEYWORDS}

fairness, justice, love, rationality

CORRESPONDENCE

Phone: -

E-mail: oinike21121986@gmail.com

\begin{abstract}
A B S T R A C T
This article discusses when justice meets love; it is a comparative study on the theory of justice according to John Rawls, and Reinhold Niebuhr. Peoples live on this earth as homosocious who interact socially with other human beings. To maintain this social relation, the need for justice is an essential element. Several theories about justice have been developed as guidelines. However, there is no single theory or a single way to define justice that is satisfying for all. In this paper, the author will compare two thinkers, namely John Rawls, with his social contract theory and Reinhold Niebuhr with his theory of justice according to Protestant ethics. This paper aims to find meeting points from these two thinkers on their concepts of justice and love.
\end{abstract}

\begin{abstract}
A B S T R A K
Manusia hidup di bumi ini sebagai homosocious yang berinteraksi secara sosial dengan sesama manusia. Untuk menjaga interaksi sosial ini, maka kebutuhan akan keadilan adalah elemen penting. Beberapa teori tentang keadilan telah dikembangkan sebagai panduan, namun mesti disadari bahwa tidak ada teori maupun cara tunggal untuk mendefinisikan keadilan yang memuaskan untuk semua. Dalam tulisan ini, penulis memilih untuk membandingkan dua pemikir teori keadilan, yakni John Rawls dengan teori kontrak sosialnya dan Reinhold Niebuhr dengan teori keadilan menurut etika Protestan. Metode yang dipergunakan penulis adalah kajian pustaka. Tulisan ini bertujuan untuk mencari titik temu kedua pemikir ini pada konsep mereka tentang keadilan dan kasih.
\end{abstract}

Kata kunci: kasih agape, keadilan, rationalitas

\section{PENDAHULUAN}

$\mathbf{T}$ eori-teori keadilan yang berkembang saat ini telah berusaha untuk memberi panduan bagi pencarian keadilan. Latar belakang dari penulisan artikel ini adalah kesadaran bahwa kebutuhan akan landasan, prinsip dan nilai keadilan tidak hanya kebutuhan pada ranah sosial, ekonomi maupun politik saja. Komunitas Kristen juga tidak lepas dari kebutuhan akan keadilan. Persoalannya, adakah di antara teoriteori keadilan yang berkembang di dunia sosial 
dan ekonomi saat ini dapat dihubungkan dengan prinsip keadilan dan nilai dasar kekristenan? Melalui tulisan ini, penulis berusaha memberi alternatif pemikiran pada kebutuhan ini dengan mempertemukan teori keadilan menurut John Rawls dan teori keadilan berdasarkan etika Protestan menurut seorang teolog Kristen bernama Reinhold Neibuhr.

\section{Teori Keadilan Menurut John Rawl}

Teori keadilan oleh John Rawl berusaha memberi jawaban bagi blind spot teori keadilan yang lebih awal diperkenalkan John Stuart Mill. Mill lebih dahulu memperkenalkan model utilitarianisme untuk pencapaiaan keadilan. Bagi Mills, keadilan diukur berdasarkan moralitas yang menghasilkan keadaan terbaik, dengan jumlah kebahagiaan terbesar, bagi lebih banyak orang. Kritik pada teori Mill adalah kecondongannya yang berorientasi pada tujuan dan kurang memperhitungkan rasa keadilan bagi pihak yang lebih lemah. Oleh karena itu, Rawls menawarkan konsep keadilan sebagai fairness. 12

Keadilan sebagai fairness dimungkinkan terjadi bila setiap pihak memiliki posisi yang setara. Kesetaraan hanya dapat dicapai dalam proses pencarian keadilan dengan tidak memandang atau memperhitungkan status sosial, kelas, kekayaan, distribusi aset, juga keistimewaan pada pihak tertentu seperti kemampuan alami, kecerdasan, kekuatan atau kekuasaan. Rawls mengasumsikan setiap pihak tidak mengetahui atau mengabaikan konsepsi mereka tentang kebaikan atau kecenderungan psikologis khusus mereka.

Bagi Rawls, keadilan diputuskan di balik veil of ignorance yakni prinsip dalam masyarakat untuk tidak memiliki jenis pengetahuan tertentu yang mungkin membuat proses tawar-menawar menjadi tidak adil. Setiap pihak diandaikan tidak memperhitungkan posisi yang mereka pegang dalam masyarakat. Oleh karena itu, perlu disadari dua hal penting. Pertama, setiap pihak sepakat untuk tunduk pada 'keadaan setara.' Kedua, setiap pihak memahami tentang

1 John Rawl, A Theory of Justice, Revision. (Cambridge: Harvard University Press, 1999), 10.

2 John Rawls, "A Theory of Justice," in Essays and Reviews: 1959-2002 (Princeton University Press, 2014), 82-87. teori ekonomi, organisasi sosial dan psikologi manusia. ${ }^{34}$ Veil of ignorance berfungsi untuk memastikan bahwa sejak awal tidak ada yang diuntungkan atau dirugikan dalam pilihan prinsip kesetaraan. Posisi awalnya adalah berupa status quo yang sesuai dan dengan demikian kesepakatan mendasar dicapai secara adil. $5^{5}$

Pada kondisi-kondisi tertentu, kedua belah pihak dapat memilih dua prinsip keadilan. Pertama, mereka dapat memilih equal liberty (kebasan yang setara) dimana setiap orang memiliki hak yang sama untuk mencapai kebebasan yang setara pada keseluruhan sistem yang paling luas. Kedua adalah difference principle (prinsip pembeda). Pada prinsip ini dimungkinkan ketidaksetaraan dalam distribusi keadilan, namun hanya bagi pihak yang dilindungi atau yang paling dirugikan dalam masyarakat. Singkatnya, ada strategi yang ditetapkan sejak awal bahwa setiap pihak dapat memilih cara untuk 'memaksimalkan yang minimum.' Bagi institusi di area sosial dan ekonomi dapat dibangun kesepakatan bersama, misalnya: (a) Keuntungan terbesar adalah bagi pihak yang paling dirugikan. Hal ini konsisten dengan prinsip ekonomi yang adil, (b) Kesepakatan pada jabatan dan posisi yang terbuka untuk semua dalam kondisi kesetaraan dan kesempatan yang adil. 6

Beberapa prinsip untuk mencapai keadilan menurut Rawls adalah: Pertama, keadilan sebagai fairness menghasilkan 'keadilan prosedural murni'. Dalam keadilan prosedural murni tidak ada standar untuk memutuskan apa yang adil selain dari prosedur itu sendiri. Keadilan berlaku bukan pada hasil atau tujuannya tetapi pada sistemnya. Rawls mengembangkan konsep 'kesempatan yang sama' sebagai prinsip keadilan. Oleh karena itu, pada posisi awal struktur dibangun melalui pilihan prosedur. Kedua adalah metode penilaian yang disebut 'keseimbangan reflektif.'

3 Karen Lebacqz, Six Theories of Justice: Perspective from Philosophical and Theological Ethics (Minneapolis: Augsburg Publishing House, 1987), 34.

4 Arthur Krentz, "Six Theories of Justice: Perspectives from Philosophical and Theological Ethics," Consensus 14, no. 2 (1988): 19.

${ }^{5}$ Lebacqz, Six Theories of Justice: Perspective from Philosophical and Theological Ethics, 11.

6 Ibid., 37. 
Metode ini melibatkan pengujian deskriptif posisi awal dengan melihat apakah ia menghasilkan prinsip-prinsip yang benar-benar cocok dengan keyakinan akan keadilan.

\section{Teori Keadilan Berdasarkan Etika Protestan Menurut Reinhold Niebuhr}

Bagi Reinhold Niebuhr, etika Kristen Protestan dimulai dengan dasar kasih. Kasih adalah 'hukum utama' dari hakikat manusia dan prinsip tertinggi etika Kristen. Dalam hal ini, Niebuhr membedakan 'kasih yang mutual' dengan kasih sebagai 'pengorbanan diri'. ${ }^{7}$ Jika seandainya manusia tidak mementingkan diri sendiri dan penuh dengan kasih, maka tidak ada kebutuhan akan keadilan karena semua hidup berdampingan dalam harmoni kasih yang sempurna. Sayangnya, dalam dunia ril, tidak ada kemungkinan seperti itu. Perintah untuk mengasihi sejajar dengan fakta dosa manusia. Di sini, Niebuhr berusaha realistis dengan dosa sebagai dasar pendekatannya dalam etika sosial. Kasih adalah sebuah 'kemungkinan dalam ketidak-mungkinan' - ia relevan sebagai standar utama dimana semua perbuatan manusia akan dihakimi. ${ }^{8}$

Bagi Niebuhr, keadilan adalah terminologi beragam yang mengandung paradox. Keadilan tidak lepas dari pembahasan tentang 'semangat keadilan', 'aturan', 'struktur keadilan,' 'kalkulasi hak' dan lebih sering tentang keseimbangan kekuasaan dan persaingan kepentingan. Menurutnya, 'keadilan yang hanya sebatas keadilan adalah keadilan yang kurang.' Keadilan yang sempurna adalah keadaan 'persaudaraan' dimana tidak terjadi konflik kepentingan. Namun keadaan demikian adalah suatu ketidakmungkinan dalam dunia yang penuh dengan dosa.

Keadilan yang sempurna hanya dimungkinkan bila terjadi kasih. Hanya saja, karena kasih yang sempurna tidak dapat diwujudkan secara penuh, demikian juga keadilan yang sempurna tidak dapat dicapai dengan penuh. Agar realistis, keadilan harus memahami kuasa di balik kepentingan berbagai pihak. Dalam sejarah manusia, kita selalu hidup dalam realita 'keadilan yang tidak sempurna' atau 'keadilan relatif.' Hal yang tidak

\footnotetext{
7 Ibid., 84.

8 Ibid., 85.
}

terhindarkan inilah yang sering kali tidak dipedulikan oleh pemikir Kristen, kata Niebuhr. Keadilan yang relatif ini mencakup persaingan kepentingan, hak dan kewajiban spesifik, serta keseimbangan pengaruh atau kuasa.

Menurut Niebuhr, ada prinsip-prinsip umum yang dipakai untuk menilai sejarah. Ada dua yang paling penting yakni kebebasan dan kesetaraan. Kebebasan adalah esensi hakikat manusia. Kebebasan tidak dapat berdiri sendiri sebagai prinsip sosial; ia harus selalu didelegasikan kembali pada keadilan, komunitas dan kesetaraan. Kesetaraan bagi Niebuhr adalah standar tertinggi dari keadilan. Kesetaraan adalah prinsip regulatif dari keadilan. Keadilan yang setara adalah 'kemungkinan paling rasional dari tujuan sosial.' Aturan terhadap kesetaraan mencakup perhatian pada proses dan juga tujuan. Keadilan yang setara memberi ruang untuk 'preferential option for the poor.'

Lalu, bagaimana keadilan bisa dibangun? Pertama, akal manusia seharusnya memiliki peran dalam mewujudkan keadilan melalui konstitusi. ${ }^{9}$ Namun dalam perjalanan sejarah, Niebuhr menunjukkan bahwa perkembangan rasionalitas telah benar-benar melukai pencarian keadilan sosial dengan 'memberikan pretensi universal' pada kepentingan sosial parsial. Kelas-kelas istimewa secara khusus bersalah atas bentuk dosa ini karena mereka tidak menyadari betapa kalkulasi perhitungan rasional mereka dipengaruhi oleh kepentingan ekonomi mereka. Memang, Niebuhr memberikan semacam 'hak istimewa epistemologis' kepada yang tertindas. Baginya, 'mereka yang mendapat manfaat dari ketidakadilan sosial secara alami kurang mampu memahami karakter aslinya daripada mereka yang menderita karenanya.' Sebagian karena distorsi dengan alasan bahwa tidak ada standar keadilan 'rasional' universal. Karena alasan ini pula 'netralitas' dalam perjuangan sosial tidak mungkin.

Kedua, rasio saja tidak cukup untuk menegakkan keadilan. Keadilan membutuhkan penggunaan kekuatan atau paksaan untuk membangun ketertiban. Bagi Niebuhr, kekuasaan menghasilkan ketidakadilan. Oleh karena itu, keadilan dalam sistem sosial tidak

\footnotetext{
${ }^{9}$ Ibid., 87.
} 
hanya soal bagaimana keadilan itu didistribusikan, tetapi juga merupakan pertanyaan tentang permintaan dan penyeimbangan kekuatan yang tepat. Bagi Niebuhr, perjuangan untuk keadilan adalah perjuangan untuk meningkatkan kekuatan bagi korban ketidakadilan.

Berdasarkan teori keadilan menurut Rawls dan Niebuhr di atas, beberapa pertanyaan berikut menjadi substasi kajian dalam artikel ini, yakni pertama apakah teori keadilan menurut John Rawls dapat dihubungkan dengan teori keadilan dari perspektif etika Kristen Protestan menurut Niebuhr? Kedua, apakah konsep dasar yang dapat dipakai untuk membandingkan teori Rawls dan Niebuhr? Terakhir, adalah di area manakah teori Rawls dan teori Niebuhr dapat mencapai titik temu?

Pada akhirnya tujuan penelitian ini adalah membuka jalan pikiran bagi perkembangan teologi Kristen ke depan untuk menjawab persoalan-persoalan keadilan yang terjadi dalam komunitas berdasarkan prinsip dan nilai-nilai dasar dalam Kekristenan.

\section{METODE}

Metode yang digunakan penulis pada tulisan ini adalah penelitian kualitatif dengan kajian pustaka. Melalui metode ini dilakukan pengumpulan data dan pengolahan bahan pustaka tanpa riset lapangan. ${ }^{10}$ Sistesis terhadap pustaka yang dikaji berguna untuk menemukan kesamaan maupun perbedaan di antaranya. Metode ini juga menyediakan dasar-dasar teori untuk mencapai tujuan penulisan sehingga berkontribusi menghasilkan pemikiran baru sebagai hasil dari penelitian.

\section{PEMBAHASAN DAN ANALISIS}

\section{Perbandingan Dasar Antropologi}

Menjadi penting untuk dibahas bersama bagaimana Rawls dan Niebuhr memahami keadilan berdasarkan latar atau sudut pandang mereka secara antropologis. Rawls terkesan lebih positif memandang kemampauan manusia untuk mencapai keadilan. Hal ini dapat ditemukan misalnya pada konsep Rawls tentang rasionalitas sebagai kebaikan dalam diri

10 Zed Mestika, Metode Penelitian Kepustakaan (Jakarta: Yayasan Obor Indonesia, 2004), 3. manusia. Kebaikan bagi Rawls menunjuk pada afinitas antara kebaikan dan kebenaran. Gagasan tentang kebaikan dalam diri manusia ini membuat ia dapat menilai kepentingan berbagai pihak di balik segala usaha mencapai keadilan. Kepentingan yang tepat adalah yang sesuai dengan norma yang diterima secara sosial.

Dengan kebaikan pada dirinya, manusia mampu untuk melakukan rencana kehidupan yang rasional. Rencana yang rasional memungkinkan seseorang untuk menyusun dan mengkoordinasikan kepentingan yang berbedabeda dan juga untuk menghubungkannya dengan kepentingan orang lain. Oleh karena itu, memiliki rencana kehidupan yang rasional dianggap sebagai hal yang baik.

Rasionalitas instrumental pada manusia kemudian membentuk dasar teori kontrak sosial Rawls. Seorang yang memiliki kepentingankepentingan tertentu secara rasional harus bekerja sama dengan orang lain, baik kerjasama yang disepakati dalam kelompok sosial maupun kesepakatan yang dengan sengaja diterima dalam sejarah. Pandangan kontrak sosial ini dikembangkan lebih lanjut dengan menambahkan pemikiran Kantian bahwa persetujuan eksplisit adalah satu-satunya dasar untuk kerjasama sosial untuk melindungi martabat seseorang. ${ }^{11}$

Berbeda dengan Rawls, latar belakang antropologis Niebuhr tentang manusia berhubungan dengan perspektifnya dari agama Kristen Protestan. Dia berpendapat bahwa tragedi sejarah manusia justru menunjukkan fakta bahwa kehidupan manusia tidak dapat kreatif tanpa menjadi destruktif. Niebuhr terlihat lebih negatif melihat rasio manusia dalam usaha mencapai keadilan yang sempurna, terlebih kasih yang sempurna. Semakin manusia berusaha untuk sempurna, ia jatuh pada dosa kesombongan. Dorongan biologis dalam diri manusia dan pengaruh roh jahat membuat manusia tidak dapat

11 V. Chaly, "Anthropological Foundations of John Rawls' Political Theory," Kantian Journal 42, no. 4 (2012): 33-38, accessed March 28, 2020, https://journals.kantiana.ru/eng/kant_collection/15 37/4394/. 
mengekspresikan dirinya sendiri tanpa melakukan dosa kesombongan. ${ }^{12}$

\section{Perbandingan Prinsip Keadilan}

Ada dua prinsip keadilan yang menjadi dasar teori Rawls, yakni:

a. Setiap orang memiliki klaim yang sama yang tak dapat ditawar terhadap skema kebebasan dasar yang sepenuhnya memadai. Skema tersebut kompatibel dengan skema kebebasan yang sama untuk semua; dan

b. Ketidaksetaraan sosial dan ekonomi harus memenuhi dua kondisi: pertama, ia harus dimuat secara resmi dan terbuka untuk semua dalam kondisi kesetaraan atas kesempatan yang adil; dan kedua, ia harus memberi manfaat terbesar bagi anggota masyarakat yang kurang diuntungkan.

Kedua prinsip keadilan menurut Rawls berperan di berbagai tingkatan. Prinsip pertama yakni kebebasan yang setara dimuat dalam perjanjian dimana kebebasan mendasar individu, kebebasan hati nurani dan kebebasan berpikir dilindungi oleh konstitusi dengan proses implementasi yang adil. Prinsip kedua membentuk aturan dimana kebijakan sosial dan ekonomi harus ditujukkan untuk "memaksimalkan harapan jangka panjang dari yang paling tidak diuntungkan dalam kondisi kesetaraan akan kesempatan yang adil."13

Dengan demikian, kedua prinsip tersebut dibangun di atas landasan utama negara yakni untuk memastikan perlindungan bagi semua warga negara. Kebebasan yang setara adalah persyaratan utama. Kebebasan tidak dapat dikorbankan untuk keuntungan ekonomi dan sosial yang lebih besar. Rawls memandang pemahaman umum tentang keadilan sebagai fairness yang membuat demokrasi konstitusional karena "kebebasan dasar rezim demokratis dijamin kuat oleh konsepsi keadilan ini."14 Inilah inti dari pandangan Rawls tentang kontrak sosial bahwa manusia didefinisikan sebagai tujuan, bukan hanya sebagai sarana.

12 Reinhold Niebuhr, Christian Realism and Political Problems, 1st ed. (NY: Charles Schribner's Sons, 1953), 201.

${ }^{13}$ Ibid., 199.

14 Ibid., 243.
Mengenai kebebasan dasar warga negara, Rawls mencakup kebebasan politik bersamaan dengan kebebasan berbicara dan berkumpul; kebebasan hati nurani dan kebebasan berpikir; kebebasan individu bersama dengan hak untuk memiliki milik pribadi; dan kebebasan dari penangkapan dan penyitaan sewenang-wenang sebagaimana didefinisikan oleh konsep supremasi hukum. Bila prinsip pertama adalah prinsip kesetaraan yang kokoh, maka prinsip kedua adalah salah satu dari ketidaksetaraan yang dimaklumkan. Oleh karena itu, beberapa ketidaksetaraan dimungkinkan tetapi hanya bagi mereka yang dilindungi atau yang berada di posisi yang paling tidak diuntungkan dalam masyarakat.

Di sisi lain, prinsip keadilan bagi Niebuhr terkait dengan pemahamannya tentang agama Kristen. Niebuhr menghubungkan dosa kesombongan dan inferioritas yang dirasakan manusia di hadapan keterbatasan mereka. Manusia dalam dirinya memiliki keinginan untuk membangun kekuatan atas orang lain untuk mengurangi perasaan ketidakberdayaannya. Niebuhr kemudian mengklaim bahwa dosa kesombongan dan egoisme menunjuk pada kurangnya kepercayaan pada Tuhan. Itu adalah dosa dasar manusia. ${ }^{15}$ Niebuhr berpandangan bahwa kaum rasionalis seharusnya menggunakan pengetahuan tentang keadilan yang sempurna meskipun standar manusia sendiri akan selalu gagal menjadi sempurna, tidak peduli seberapa cerdas manusia itu.

Bagi Niebuhr, realisasi diri adalah penerimaan diri sebagai yang terbatas. Dosa adalah hasil dari kurangnya kepercayaan dan iman kepada Tuhan. Jadi hanya di dalam dan melalui Tuhanlah kecemasan yang disebabkan oleh keterbatasan umat manusia dapat diatasi. Kehendak Tuhan harus menjadi norma bagi kehidupan apa pun yang diinginkan seseorang untuk mengatasi dosanya, meskipun bagian dari realisasi diri ini adalah kesadaran bahwa manusia tidak pernah bebas dari dosa. Kebebasan menjadi alat bagi dosa. Oleh karena itu, manusia harus memiliki rasa keadilan dan kesetaraan atau perasaan paling dasar tentang apa yang benar karena manusia harus dapat

${ }^{15}$ Reinhold Niebuhr, The Nature and Destiny of Man: A Christian Interpretation (London: Nisbet \& Company Limited, 1941), 258. 
mengenali, sampai batas tertentu, apa yang adil, apa yang tidak adil dan apa yang salah. ${ }^{16}$

Keadilan asali dan hukum kodrat tidak dapat dipisahkan karena kebebasan manusia yang menetapkan setiap standar keadilan di bawah kemungkinan yang lebih tinggi. Kebenaran asali dialami secara transenden. Namun, dosa muncul di antara kebebasan dan keterbatasan karena di luar sejarah manusia tidak berdosa, tetapi begitu ia bertindak dalam sejarah, ia mulai berdosa. Di dalam dan dengan kebebasan manusia, ia berdosa karena kasih diri dan keterpusatan diri tidak bisa dihindari. ${ }^{17}$

\section{Perbandingan Konsep Kasih}

Rawls menempatkan kasih sebagai prioritas utama dari prinsip keadilan karena baginya kasih tidak memihak atau adil. Ketika kepentingan berbenturan, keputusan atas dasar kasih akan dipandu oleh apa yang akan disetujui oleh masyarakat dalam situasi awal yang adil yang memberi mereka kesetaraan yang sama sebagai orang bermoral. ${ }^{18}$ Dengan demikian, jelas bahwa bagi Rawls tidak ada tempat untuk kasih di posisi awal. Baginya keadilan adalah soal keinginan untuk bertindak adil, sedangkan kasih melampaui keadilan. Kasih dipahami tidak hanya sebatas memenuhi semua kewajiban tetapi melampaui persyaratan akan keadilan itu. Difference Principle menyediakan cara di mana kasih dapat menjadi fairness karena pada akhirnya, kasih akan berusaha bergerak melampaui keadilan dengan memberi lebih dari apa yang dibutuhkan.

Menurut Niebuhr, hubungan antara kasih dan keadilan tetap paradoks di seluruh karyanya karena kasih dipandang sebagai pemenuhan dan negasi hukum. ${ }^{19}$ Dia menolak kasih (agape) sebagai pengharapan untuk perubahan dalam masyarakat sementara pada saat yang sama mempertahankan pentingnya kasih dalam masyarakat. Dia mengerti kasih (agape) dalam terang salib, bukan dalam soal mengekspresikan kasih altruistik. Pandangan

16 Ibid., 280.

17 Ibid., 263.

18 John Rawls, A Theory of Justice (Oxford, UK: Oxford University Press, 1971), 191.

${ }^{19}$ Reinhold Niebuhr, Beyond Tragedy: Essays on the Christian Interpretation of History (New York: C. Scribner's Sons, 1937), 269. tentang kasih sebagai pengorbanan diri yang lengkap memungkinkan Niebuhr lebih negatif atas kemampuan manusia untuk mengasihi daripada yang sebenarnya mungkin. Manusia tidak dapat mengasihi secara sempurna.

Meskipun semua orang melanggar hukum kasih, beberapa orang melakukannya sampai taraf yang lebih besar daripada orang lain. Jadi, kasih tentu tidak kehilangan prioritasnya di dunia. Kasih adalah hukum kehidupan dan bukan sekadar cita-cita kesempurnaan yang transenden. Semua orang mungkin melanggar hukum kehidupan tetapi ada perbedaan antara mereka yang berusaha menarik semua kehidupan ke dalam diri mereka sendiri, dan mereka yang telah menemukan Tuhan di pusat kehidupan melalui kesetiaan kepada-Nya dan telah belajar untuk menghubungkan diri mereka dalam hal saling melayani untuk sahabatsahabat-Nya. ${ }^{20}$ Niebuhr menggunakan agape sepanjang karyanya untuk merujuk pada elemen transenden yang terus-menerus memenuhi syarat kasih indrawi kita, kasih yang mutual, kasih untuk keluarga, dan tanggung jawab kita kepada komunitas.

\section{Kritik atas Teori Keadilan Rawls and Niebuhr}

Tantangan bagi teori Rawls tentang keadilan sebagai fairness adalah mengenai konsep epistemologisnya tentang 'selubung ketidaktahuan,' Karen Lebaque misalnya berpandangan bahwa kendati selubung ketidaktahuan disepakati, pihak-pihak di posisi semula masih dianggap memiliki pengetahuan umum tentang bidang-bidang seperti politik dan teori ekonomi. Wolff juga memberi kritik bahwa bahwa tidak mungkin ada pengetahuan 'umum' yang tidak berdasarkan pengetahuan tertentu. Sebagai contoh, teori-teori ekonomi yang sudah memiliki bias di dalamnya. Dengan demikian, tidak mungkin bagi para pihak dalam posisi semula untuk memiliki pengetahuan umum yang tidak memihak; semua pengetahuan umum didasarkan pada dan mengungkapkan kekhasan dan bias. ${ }^{21}$

Beberapa kritikus lain mencatat bahwa dalam keadaan selubung ketidaktahuan, kontrak sosial benar-benar menjadi semacam

${ }^{20}$ Ibid., 258.

${ }^{21}$ Lebacqz, Six Theories of Justice: Perspective from Philosophical and Theological Ethics, 41. 
rasionalitas individu yang tertulis. Karena selubung ketidaktahuan menghilangkan ciri-ciri yang membedakan setiap pihak untuk menentukan arah keputusan mereka. Rawls sendiri mengakui kelemahan ini. Dia mengusulkan bahwa kontrak itu benar-benar merupakan 'perspektif' yang dapat diadopsi oleh siapa pun yang mau menempatkan dirinya di bawah selubung ketidaktahuan yang diperlukan.

Sedangkan kritik yang paling inklusif pada teori Niebuhr adalah tuduhan bahwa ia tidak memiliki teori keadilan. Brunner misalnya mengatakan dengan tegas bahwa Niebuhr tidak pernah menemukan konsep keadilan yang jelas di mana perbedaan antara tuntutan keadilan dan tuntutan norma etika kasih tertinggi dapat dipahami. Di sisi lain, Harland membela Niebuhr. Ia berpendapat bahwa kegagalan untuk mendefinisikan suatu istilah tidak berarti bahwa seseorang tidak memiliki konsep yang diartikulasikan secara jelas. Keadilan tidak didefinisikan oleh Niebuhr karena bagi Niebuhr keadilan adalah istilah relasional yang tidak memiliki arti independen dari konsep kasih. Hal senada disampaikan oleh Niebuhr untuk menanggapi kritik yang dilontarkan padanya. Ia mengatakan bahwa keadilan adalah penerapan hukum kasih. Keadilan tidak terpisah dari kasih. Bagaimanapun juga, kritik pada Niebuhr mencerminkan kurangnya teori sistematis Niebuhr tentang keadilan. Pendekatan Niebuhr adalah teknik kenabian, alih-alih teknik filosofis.

\section{DIKSUSI: Pandangan Personal Penulis}

Rawls dan Niebuhr menawarkan teori keadilan yang menarik untuk didiskusikan. Keduanya sama-sama dipertemukan lewat pandangan mereka tentang keadilan dan kasih. Jenny Wright dalam disertasinya mengklaim bahwa optimisme Rawls dan realisme Niebuhr menawarkan keseimbangan yang baik bagi diskusi kritis. ${ }^{2223}$ Filsafat sosial Rawls dilengkapi

22 Jenny Anne Wright, Justice Between Fairness and Love? Developing a Christian Notion of Justice in Critical Dialogue with John Rawls and Reinhold Niebuhr (Cape Town: Stellenbosch University, 2011), 239.

${ }^{23}$ Jenny Anne Wright, "Justice between Fairness and Love? Christian Ethics in Dialogue with Rawls and Niebuhr," International Journal of Public Theology 6, no. 3 (2012): 306-328, https://brill.com/view/ journals/ijpt/6/3/article-p306_4.xml. oleh etika teologis Niebuhr dan membawa kedua ilmuwan ke dalam dialog tentang kasih dan keadilan.

Gagasan alkitabiah tentang perlindungan bagi mereka yang lemah/miskin (preferential option for the poor) adalah bagian penting dari keadilan. Meskipun pembahasan ini tidak menonjol dalam karya Rawls, namun ia cukup mendeskripsikannya pada prinsip kedua tentang keadilan yakni dimungkinkannya difference principle yang memberi manfaat terbesar bagi pihak/masyarakat yang kurang diuntungkan. Dengan prinsip ini pula, Rawls memungkinkan perlindungan terhadap martabat manusia. Dalam konsep alkitabiah kita diharapkan menghargai martabat setiap orang dan memandang dengan serius kebutuhan mereka akan rasa hormat.

Difference principle juga memberi ruang untuk kasih dalam wujud solidaritas kepada mereka yang kurang diuntungkan dalam masyarakat. Komunitas masyarakat sangat penting untuk pengembangan nilai-nilai dan rasa hormat. Manusia harus memiliki tempat di mana mereka dapat belajar untuk memperlakukan satu sama lain dengan adil dan setara. Dalam komunitas, manusia dapat belajar berpikir etis dan mengembangkan karakter moral yang sehat dengan penekanan pada tanggung jawab dan tugas.

Kendati bagi Rawls, kasih tidak menjadi bagian dalam teori keadilan secara eksplisit namun ia memahami kasih sebagai konsep yang melampaui keadilan. Bila keadilan adalah soal cara untuk mencapai kesetaraan, kasih lebih dari itu. Kasih memungkinkan seseorang bertindak lebih dari perjuangan kesetaraan. Namun dalam kontrak sosial, kasih tidak dapat menjadi ukuran awal dalam mencari cara untuk mencapai keadilan.

Niebuhr memandang konsep kasih Tuhan (agape) sebagai tolok ukur terhadap keadilan manusia. Kasih inilah yang akhirnya diperjuangkan sebab kasih mencari sesuatu yang lebih dari keadilan. Kasih mengingatkan kita akan nilai setiap orang juga kebutuhan manusia akan rasa hormat dan martabatnya. Niebuhr menghubungkannya dengan pandangan eskatologis tentang pengharapan. Baginya hanya sekedar berharap untuk masa depan yang lebih baik tidak cukup; harapan itu 
seharusnya dorongan untuk mencari lebih banyak keadilan setiap hari.

Gereja harus menjadi sangat kritis tentang bagaimana keadilan diterapkan dalam masyarakat. Gereja juga perlu memberi perhatian bahwa kegagalan institusi manusia adalah ketika ia tidak mampu sepenuhnya mewujudkan keadilan. Kendati demikian, kita tidak menyerah pada apatisme dan keputusasaan tetapi melihat, menilai dan bertindak berdasarkan apa yang dilihat. Sementara prinsip-prinsip keadilan yang menyeluruh, universal, dan historis mungkin menarik sebagai tolok ukur yang diperlukan untuk menilai keadilan maupun ketidakadilan.

Untuk menemukan solusi untuk situasi ketidakadilan tertentu dan untuk memperbaiki kejahatan saat ini dibutuhkan solusi spesifik yang cocok untuk komunitas kita saat ini. Bagi Niebuhr keadilan selalu mengarah ke sesuatu yang lebih. Yang dibutuhkan adalah peningkatan makna hidup, nilai hidup dan penolakan untuk menerima sesuatu yang kurang. Kehidupan kita bukanlah institusi dan tidak seharusnya diperlakukan seperti itu. Keterbatasan institusi yang mengatur kehidupan kita perlu dipisahkan dan dipertanggungjawabkan pada hukum yang berbeda.

Bagi iman Kristen, kasih memainkan peran penting sebagai dasar setiap diskusi tentang keadilan. Tetapi konsep kasih yang abstrak adalah etika yang sulit diterapkan pada komunitas politik atau institusi. Di komunitas sosial, konsep Rawls tentang keadilan sebagai fairness dapat menjadi pertimbangan.

\section{KONKLUSI}

John Rawls dan Reinhold Niebuhr menawarkan konsep keadilan berbeda yang dapat dipertimbangkan oleh komunitas sosial masyarakat. Rawls melalui teorinya cukup optimis pada kemampuan manusia untuk mencapai jalan keadilan sebagai fairness. Bagi Rawls, kasih adalah konsep yang melampaui keadilan. Di sisi lain, Niebuhr berusaha realistis dengan hakikat manusia yang penuh dengan dosa. Karena realitas dosa pada dirinya, manusia tidak mungkin mencapai keadilan sempurna alih-alih kasih yang sempurna. Setiap usaha manusia untuk mewujudkan agape dengan kekuatannya sendiri, saat itu juga manusia terjebak dalam dosa kesombongan. Walau demikian, bagi Niebuhr, manusia dengan rasionalitasnya tetap dapat dan harus mengusahakan keadilan walau keadilan itu tidak pernah seutuhnya sempurna. Rawls dan Niebuhrpun memiliki titik temu pada konsep kasih dan keadilan kepada mereka yang lebih tidak diuntungkan. Keduanya mengajak masyarakat dalam pencarian keadilan untuk berpihak kepada mereka yang lemah dan yang lebih tidak diuntungkan dalam masyarakat. Pada saat itulah kasih melebihi keadilan dan kesetaraan.

\section{REFERENSI}

Chaly, V. "Anthropological Foundations of John Rawls' Political Theory." Kantian Journal 42, no. 4 (2012): 33-38. Accessed March 28, 2020. https://journals.kantiana.ru/eng/kant_colle ction/1537/4394/.

Krentz, Arthur. "Six Theories of Justice: Perspectives from Philosophical and Theological Ethics." Consensus 14, no. 2 (1988): 19.

Lebacqz, Karen. Six Theories of Justice: Perspective from Philosophical and Theological Ethics. Minneapolis: Augsburg Publishing House, 1987.

Mestika, Zed. Metode Penelitian Kepustakaan. Jakarta: Yayasan Obor Indonesia, 2004.

Niebuhr, Reinhold. Beyond Tragedy: Essays on the Christian Interpretation of History. New York: C. Scribner's Sons, 1937.

- - - Christian Realism and Political Problems. 1st ed. NY: Charles Schribner's Sons, 1953.

- - - The Nature and Destiny of Man: A Christian Interpretation. London: Nisbet \& Company Limited, 1941.

Rawl, John. A Theory of Justice. Revision. Cambridge: Harvard University Press, 1999.

Rawls, John. "A Theory of Justice." In Essays and Reviews: 1959-2002, 82-87. Princeton University Press, 2014.

- - - A Theory of Justice. Oxford, UK: Oxford University Press, 1971.

Wright, Jenny Anne. "Justice between Fairness and Love? Christian Ethics in Dialogue with Rawls and Niebuhr." International Journal of Public Theology 6, no. 3 (2012): 306-328. https:// brill.com/view/journals/ijpt/6/3/a rticle-p306_4.xml. 
- - . Justice Between Fairness and Love? Developing a Christian Notion of Justice in Critical Dialogue with John Rawls and Reinhold Niebuhr. Cape Town: Stellenbosch University, 2011. 